\title{
Empowerment of Farmer Community Group in Sampali Village Together with Students of Agriculture Faculty Medan Area University in Barangan Banana Plants Development with Tissue Culture Banana Seeds,Suckers and Applications of Mycorrhiza
}

\author{
Suswati $^{1}$, Sumihar Hutapea ${ }^{1}$, Asmah Indrawaty ${ }^{1}$ \\ ${ }^{1}$ Faculty of Agriculture, Medan Area University, Medan, Indonesia \\ suswati@uma.ac.id
}

\begin{abstract}
Sampali Village is an agricultural area that is very suitable for banana planting. Various types of bananas found in the village include Barangan, Kepok, Molen, Raja and banana Nangka. Banana shoots from harvested mother plants are used for development in new areas. Banana seedlings from the suckers appear healthy, but often these suckers die after 1-2 months of planting in new areas. This is because these bananas have been infected with fungal pathogen wilt caused by Fusarium oxysporm $f$. sp cubense and Ralstonia syzygii subsp. celebesensis causes of blood diseases. Both of these pathogens are the main cause of the low quality of banana seeds. The use of low-quality banana seedlings (sapling sources), high pest and disease attacks are the factors causing the reduced amount of banana planting land which results in low banana production in Sampali Village, Percut Sei Tuan District, Deli Serdang Regency. Banana farmer groups in the village of Sampali have never used and planted banana seedlings that were propagated by tissue culture. The objectives of the activity were: 1 . Socialization and practice of propagation of banana seedlings from sucker. Mycorrhizal inoculant application when planting seedlings in a polybag. To increase the knowledge of farmer group members and also the students of Agricukture Faculty,Universitas Medan Area the learning of banana propagation techniques is carried out in vitro at the Balai Benih Induk Hortikultura, Gedung Johor Medan. The method used to solve the above problems is the provision of material, the practice of making banana seedlings through the propagation of tillers and a visit to the Balai Benih Induk Hortikultura, Gedung Johor Medan. At the end of the activity, an increase in the knowledge and skills of participants in providing quality banana seeds is the source of banana propagation in the village Sampali
\end{abstract}

Keywords: community farmers group; Sampali Village; banana plants; propagation,Medan Area University

\section{Introduction}

Banana is a fruit that has a bright prospect to be developed because it has various advantages including: it is a source of alternative carbohydrates in addition to rice, sweet potatoes and corn, can grow in the highlands/lowlands on various types of soil and high nutrient content. On average in every $100 \mathrm{~g}$ of banana meat contains $70 \mathrm{~g}$ of water, $1.2 \mathrm{~g}$ of protein, $0.3 \mathrm{~g}$ of fat, $2.7 \mathrm{~g}$ of starch, $0.5 \mathrm{~g}$ of fiber, $400 \mathrm{mg} / 100 \mathrm{~g}$ of potassium and the energy contained in every $100 \mathrm{~g}$ of banana flesh in the amount of $275 \mathrm{~kJ}-465 \mathrm{~kJ}$ (Ashari, 2006).

Barangan Banana or better known as Medan Barangan is a type of banana that can be eaten directly after being riped, while Kepok bananas are classified as bananas that must be processed first before being consumed such as boiling, fried chips or processed into other foods.Both types are bananas that high demand in North Sumatra.Barangan banana plantations are a banana commodity that is widely planted in the village of Sampali, especially planted in new areas in former PTPN II arable land.

Conventionally Barangan bananas are propagated with suckers and beets, which can 
produce 1-10 tillers in one year (Meina, 1992). Based on the results of a survey conducted by the Medan Area community services program (CSP) team, data was obtained that the United People's Farmer Group (Kelompok Tani Masyarakat Bersatu) used suckers in the expansion of banana plants.Banana seedlings are obtained from banana clumps whose parents have been harvested.

The quality of these Barangan and Kepok banana suckers is often of poor quality because in general they come from clumps which are attacked by weevils and wilt disease. Farmers prefer the use of suckers over tissue culture seeds on the grounds that the price of tillers is only Rp.3000-5000 compared to the price of seedlings derived from tissue culture Rp.8000/seedlings. In addition, tissue culture seedlings must be ordered at least 6-12 months before planting, this causes members of farmer groups to be reluctant to use tissue culture seeds.

To transfer knowledge, science and technology about the propagation of banana plants through tissue culture seedlings and tillers that are applied with mycorrhiza,community service program (CSP) have been carried out in the form of science and technology transfer programs in Barangan and Kepok banana nurseries. The purpose of this activity is to increase the knowledge and skills of farmer groups and student of Agriculture faculty is in the propagation of banana plants through tissue culture seeds, propagation of banana suckers that are applied with mycorrhiza.

\subsection{Partner selection}

\section{Research Method}

The partners of this activity are the Unified Community Farmer Group in Sampali Village,Percut Sei Tuan District,Deli Serdang Regency, North Sumatra and under graduatestudents of the Faculty of Agriculture,Medan Area University.The selection of these farmer groups is based on farmer groups that intensively develop banana cultivation Barangan and Kepok are experiencing problems in the acquisition of quality banana seeds and under graduate students who are completing a thesis.

\subsection{Technology Transfer}

Partner problems are overcome by a number of technological solutions carried out by the technology transfer method through education, training, and comparative studies (a visit to the Balai Benih Induk Hortikultura,Gedung Johor Medan).Propagation of banana plants is done by separating tillers from Barangan plant harvested,mycorrhiza application and seedling maintenance.The training material was delivered using counseling methods, discussion and practice.To increase the knowledge and insight of farmers and students about the propagation of bananas through tissue culture, at the end of the activity a visit was made to the tissue culture laboratory of the Balai Benih Hortikultura Gedung Johor,Medan.

\section{Result and Discussion}

\subsection{Profile of Participants in Banana Plant Propagation Empowerment}

Kelompok Tani Masyarakat Bersatu (KTMB) is one of the farmer groups that manage the former PTPN II land in Sampali Village, Percut Sei Tuan District,Deli Serdang Regency. This group has 70 members with a land area of 70 Ha.This farmer group plants various plants such as bananas,corn and cassava.As many as 25 percent of farmer group members plant banana as the main source of income, while 75 percent grow corn and cassava.

The members of the KTMB group are dominated by $90 \%$ of the men and $10 \%$ of the women and all members and administrators are married with 1-5 children. The average member is 30-60 years old with elementary school education of 7\%, middle school $32 \%$ and high school $61 \%$.The undergraduate of students at the Faculty of Agriculture of UMA who 
emails: birex.journal@gmail.com

participated in the training activity were men and aged between 21-22 years.

\subsection{Current Conditions of Banana Plants Farmers Community Unite}

Banana plant is one type of plant managed by members of the United People's Farmer Group (KTMB).This plant ranks third after the corn and cassava plants. Since the last three years, many banana plants have been developed after the area of sugar cane plantation is not continued.Planting bananas is the choice of farmer groups because of various considerations including: banana plants are easy to maintain, sapling resources are available after the parent is harvested.Banana plantations are quite once in planting, tillers will develop into new bloodstock.Usually farmers plant bananas that produce lots of tillers such as Barangan, kepok banana, Nangka banana, molen banana and emas banana.

Banana plantations of group members are generally poorly maintained. In banana plantations found leaf roller pests caused by Erionata thrax, Fusarium wilt caused by Fusarium oxysporum $f$ sp cubense and Blood disease bacterium caused by Pseudomonas celebensis and banana bunchy top virus (Figure 1). Control of various pests and diseases has never been done. Breaking bananas, cutting banana nails and buding has also never been done.
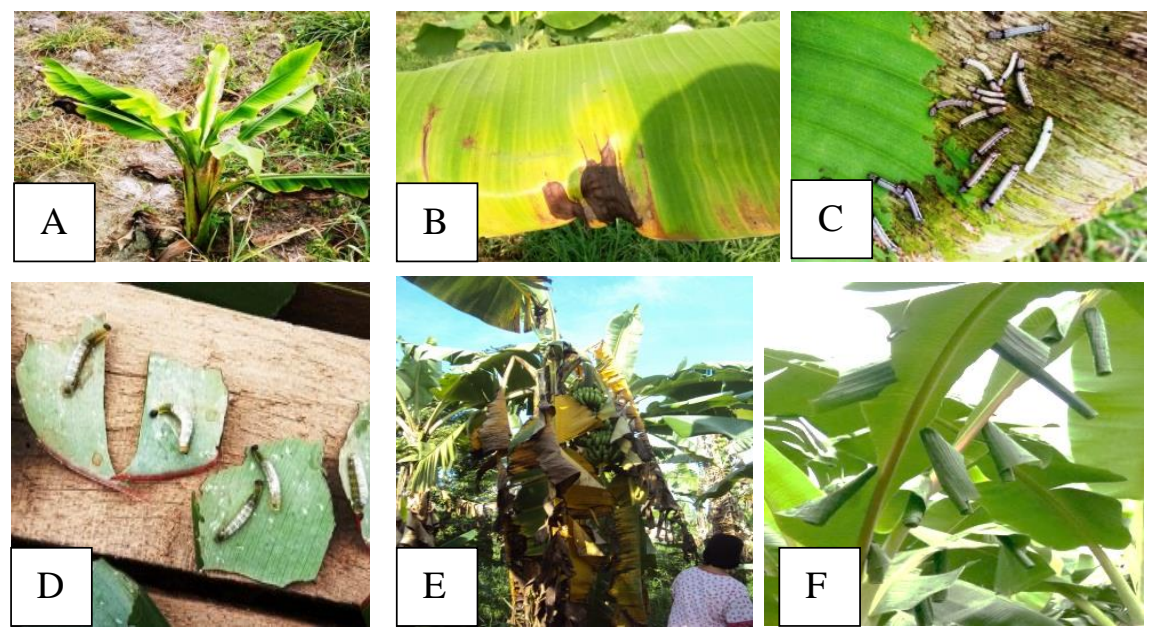

Figure 1. Pests and diseases that attack the banana plantations in the area of the Unified Community of Sampali Village, Percut Sei Tuan District, Deli Serdang, North Sumatra. Information; $\mathrm{A}=$ Bunchy top virus, $\mathrm{B}=$ Fusarium $; \mathrm{C}=$ Spodoptera $; \mathrm{D}, \mathrm{F}=$ E.thrax. Source: Suswati documentation,2019.

\subsection{Seed Propagation by Separation of Tiller}

Propagation by tiller by separating the banana suckers from their mother. This is a simple method used by many united community farmer groups in general with the following steps:

a. Separating suckers with a height of 41-100 $\mathrm{cm}$ and leaves with the shape of a sword with a pointed tip from the harvested parent.

b. Soaking the roots of bamboo shoots of $20-40 \mathrm{~cm}$ in size with the Dithane M-45 fungicide solution for 30 minutes.

c. Then the suckers are put into a $30 \mathrm{~cm}$ x $45 \mathrm{~cm}$ filled polybag (1/3 polybag) with a mixed soil and manure planting medium (3:1).

d. Sprinkle $15 \mathrm{~g}$ of mycorrhiza inoculants in the roots.

e. Furthermore, the roots of the tillers are covered with additional growing media until the base of the tillers is covered with planting media.

f. Seedlings are doused with $20 \mathrm{ml}$ of water and arranged in a $60 \%$ shade net / screen net.

g. At the age of 7 days after transplanting the seeds are sprayed with the insecticide Diazinon and Dithane M-45 fungicide according to the dosage stated on the package. 
Banana shoots that can be used as seed sources can be seen in Figure 2.
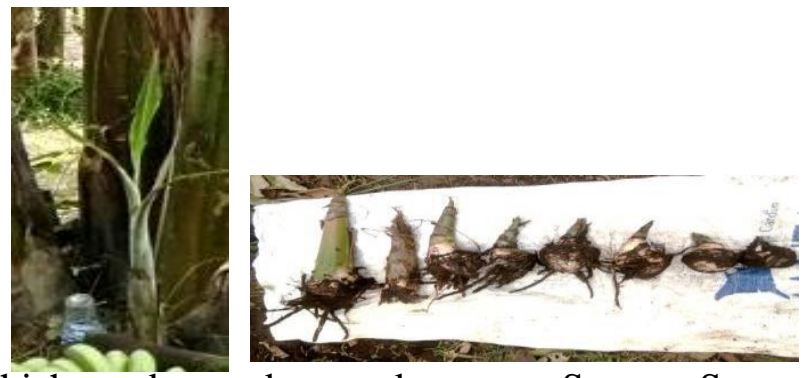

Figure 2. Banana shoots which can be used as seed sources. Source: Suswati documentation.

\subsection{Obtaining Banana Planlets}

Banana plantlets used were Barangan and Kepok cultivars from PT. Green Biotechindo North Sumatra.The seeds are the result of in vitro propagation.Banana seedlings are removed from the bottle,washed with running water until the media is not attached,then dried. To stimulate root formation the plantlet roots were cut until only $2 \mathrm{~cm}$ (Figure 3B).

\subsection{Introduction of Mikoriza}

The source of mycorrhiza inoculant used is in the form of a mixture of sand growing media containing spores, external hyphae and root pieces of corn plants colonized with mycorrhiza (Figure 3C).Introducing mycorrhiza at the same time as plantlet acclimatization. The middle part of the acclimation media (manure mixture: husk charcoal (1:3)) from each $12 \times 15 \mathrm{~cm}$ size polybag made a hole as deep as $5 \mathrm{~cm}$ is sprinkled with $10 \mathrm{~g}$ of mycorrhiza inoculant containing about 100 spores, covered with a layer of soil $(2 \mathrm{~cm})$ then plantlets are planted.

The Barangan banana polybag is placed on a wooden shelf, to keep it moist, the seeds are covered with transparent plastic with $60 \%$ lighting. Seedlings are maintained until the age of 14 days and then transferred to a poly bag containing $8 \mathrm{~kg}$ of sterile Ultisol soil in a $10 \mathrm{~kg}$ volume polybag.
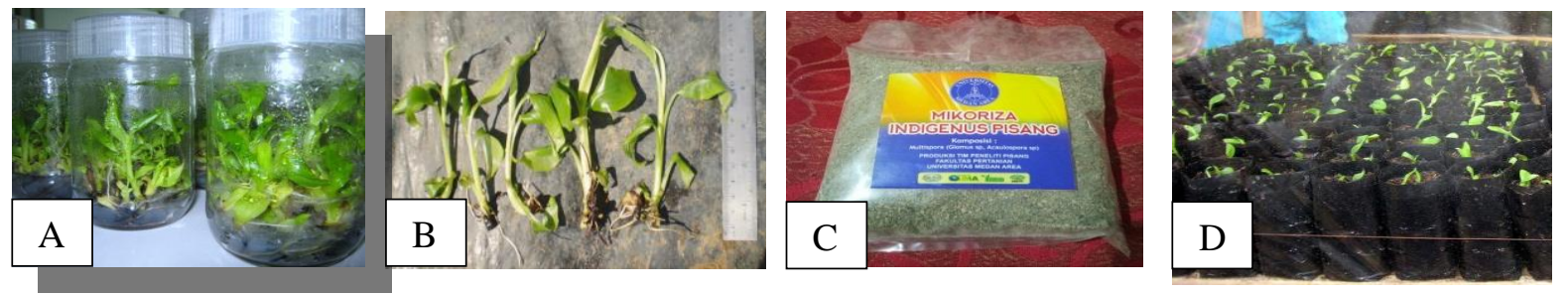

Figure 3. Stages of acclimatization of banana plantlets and mycorrhiza applications. Note: A $=$ Plantlet Barangan $; \mathrm{B}=$ Plantlet which has been washed and partially rooted $\mathrm{C}=$ mycorrhiza inoculant $; \mathrm{D}=$ Plantlet during acclimatization. Source: Suswati documentation.

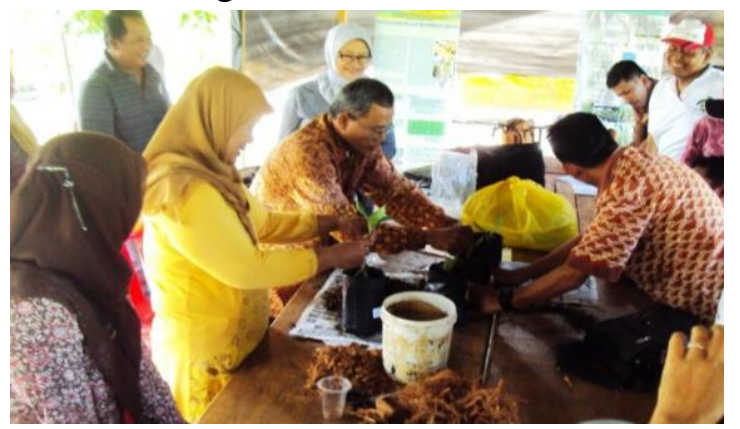

Figure 4. Participant activities in acclimatizing the Barangan banana plantlet with a mixed soil planting medium, manure and coconut fiber. 


\subsection{Maintenance of banana seeds}

emails: birex.journal@gmail.com

14-day-old banana seedlings are transferred to a 30x40 cm polybag containing $8 \mathrm{~kg}$ of soil mixture, manure, coconut coir (3: 1) that has been sterilized. The addition of coconut fiber and aims to improve water drainage and improve media aeration (Suswati et al, 2015).

At the same time fertilization is carried out with Urea, NPK and KCl. Fertilization is done once a month with a $25 \%$ recommended dose.For 1 ha of bananas requires $207 \mathrm{~kg}$ of urea, $138 \mathrm{~kg}$ of super phosphate and $608 \mathrm{~kg}$ of KCl (Subakti and Supriyanto, 1996). Seeds are watered every day to roomy capacity. Weeding and pest control is done mechanically. In Figure 5 can be seen banana seedlings tissue culture results 8 weeks after acclimation (waa).

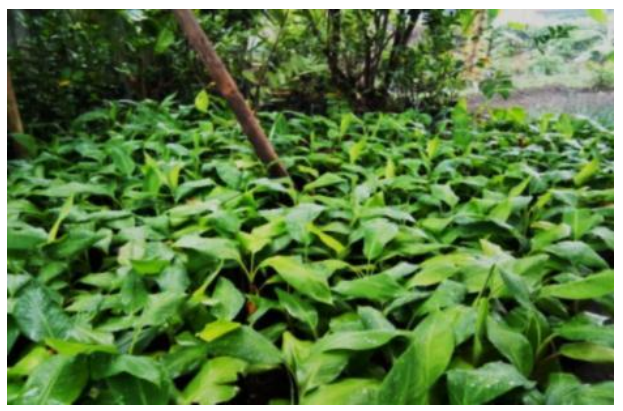

Figure 5. Barangan Banana Seeds aged 8 weeks after acclimatization.Source: Suswati documentation

\subsection{Increased knowledge and skills of participants}

Socialization and training/practice activities are able to increase the knowledge of farmer group members about plantlet acclimatization,mycorrhiza application and seedling enlargement.Before the material is pre-tested and data is obtained that the understanding and knowledge of group members prior to the pre-test of plantlet acclimatization, mycorrhiza application and enlargement of banana seeds the origin of tissue culture is very low even all members of the farmer group do not know anything about banana tissue culture, they only know the propagation of banana plants through seedlings. While the final year students are almost one hundred percent aware of tissue culture banana seeds but have never done acclimatization practices and mycorrhiza applications on banana plantlets.

To increase the knowledge and skills of group members and students about the propagation of bananas by tissue culture, acclimatization and enlargement of banana seedlings, a visit was made to the Horticultural Seed Network tissue culture laboratory of the Johor Building, Medan.

\subsection{Visit to Balai Benih Induk Hortikultura Gedung Johor,Medan.}

To improve the knowledge, insights and skills of farmer groups and final year students of FP UMA, a visit was made to the Balai Benih Induk Hortikultura Gedung Johor,Medan. Submission of material about banana tissue culture delivered by Ms. Nuriman with simulation methods.

At the beginning of the activity, a conventional and in vitro propagation ratio was compared propagation of banana seedlings conventionally using saplings or tubers requires a relatively long time. One alternative for the rapid supply of banana seeds is by propagation techniques in vitro (Yusnita et al., 1996; Kasutjianingati et al., 2011).

It was explained that the materials and equipment used for the propagation of banana plants with tissue culture techniques were: explants shoots next to the Red Barangan banana, so as a compactor,sucrose,NAA,kinetin,disinfectant (sunclin, Dithane, $70 \%$ and $95 \%$ alcohol, byclin,and sterile aquades),MS base media,glassware, analytical scales,pH meters, autoclaves, laminar air flow (LAF), dissection equipment (tweezers, scissors, scalpels), stirrers, spiritus lamps,culture racks with 40 watt lamps. 
The stage of propagation of banana plants in vitro is divided into several stages, namely: initiation of explants culture, multiplication, root and finally is the acclimation of plantlets. The final stage in plant propagation in vitro is the acclimation of plantlets. The acclimatization stage is the stage that determines the success of plant propagation in vitro (Yusnita, 2003).

After the explanation about the propagation of bananas in vitro, all participants were invited to visit laboratory facilities and practice taking explants of Barangan banana plants.

\section{Conclusion}

Socialization and training activities are able to increase the knowledge, insight and skills of farmers and students about the propagation of bananas in vitro, propagation by suckers, mycorrhiza applications and enlargement of banana seeds.

\section{Acknowledgement}

Thanks to the Chairperson of the Haji Agus Salim Siregar Foundation (YPHAS) for their financial support through the community service program Grant with Decree Number T/140/E3/ RA.00/2019 dated February 25,2019 and Agreement Letter for Implementing Partnership Programs at the University of Medan Area Community Number: 572/LP2M/04.6/VII/2019 dated July 08,2019

\section{References}

Kasutjianingati,Poerwanto R, Widodo, Khumaida N dan Efendi D. (2011). The effect of induction media on the multiplication of shoots and the growth of the pisang raja bulu pisang raja bulu $(\mathrm{AAB})$ and pisang Tanduk (AAB) plantlets on various media multiplication. J Agron Indonesia 39 (3): 180-187.

Meina, D. (1992). Cavendis Banana Cultivation Enterprises. Tissue Culture. Trubus No. 285. Jakarta.

Subakti dan Supriyanto, 1996. Subakti H \& Supriyanto B. 1996. Improvement of Banana Cultivation Techniques. Balitbangtan. Indonesia Fruit Crops Research Institute. Solok

Suswati.S, Indrawaty.A.Prima Putra.D. (2015). Screening of agricultural wastes (coconut husk and husk charcoal) in increasing the resistance of the mycorrhiza seed barangan bananas to Blood Disease Bacterium and Fusarium oxysporum f.sp. cubense. J. Tropical HPT. Vol. 15, No. 1: 81-88.

Yusnita, K. Mantja, D. Hapsoro. (1996). The effect of benzyl adenine and indolasetat acid on the multiplication of Ambon Kuning banana shoots in vitro. J. Agrotropics. Vol. 1 No. 1: 29-31.

Yusnita. (2003). Tissue Culture How to Increase Plants Efficiently. Agromedia Pustaka, Bogor. 